\title{
THE LEAF SPOT OF TOBACCO; AN AFTER SYMPTOM OF MOSAIC
}

\author{
Mervilute T. CoOK
}

Soon after coming to Puerto Rico in 1923 the attention of the writer was ealled to a peculiar spotting on the leaves of tobacco. Collections of these spotted leaves were sent in from time to time and were examined for fungi and bacteria but the results were always negative. The disease appeared to be of minor importance and $\mathrm{n}^{\circ}$ special studies were made until the winter of 1929-30. These spots were always on the mature, usually the lower, leaves of the plants. They were 2 to $5 \mathrm{~mm}$. in diameter, white, brown or black and composed of dry, dead tissues. During the winter of 1929-30 great numbers of these spots were found one morning in tobaceo mosaie experimental plots. These plots were not more than 50 feet from my laboratory and it was my habit to visit them nearly every day. Therefore, it was evident that these spots developed in a very short time. A careful examination showed that these spots were on the mosaic plants and not on the healthy plants and that they were always on the old leaves which did not show the symptoms of the mosaic, $i$. $e$. on leaves, which due to late inoculations, had not developed the symptoms or on leaves from which the pattern had disappeared. The following morning the spots were much more numerous. Plants which did not show these spots were marked and observed from day to day and it was soon learned that plants which did not show those spots one day might show a considerable number the following morning. A block of plants was then divided into two parts and the plants in one part inoculated. In clue time the spots appeared on old leaves of the diseased plants.

These spots remind one of the early studies by Mayer, Iwanowski and others. Mayer (10) reported a spotting in the late stages of the tobaceo mosaic. Iwanowski stated that Mayer had confused two c!iseases and that the spots were a disease which had been described hy himself and Polowzoft under the name of "pockenkrankheit".

He says:

"This last name I retain for that disease which is the subject of this paper, and as I have just described it never manifests itself in the form of dry spots."

In 1894 Prillieux and Delacroix described spotting of the leaves 
of the tobaceo under the name of "nielle" and from which they claimed to have isolated a motile bacillus. Some workers have supposed that this disease was the same as Mayer's "mosaikkrankheit" but this is extremely doubtful.

In 1897 Marchal described a disease under the name of "Ia Mosaicue du Tabae" which was probably the same as the disease described by Mayer. He emphasized the presence of the spots which lie also described as containing a motile bacillus.

In 1898 Beijerinck published a paper on tobaceo mosaie in which, judging from the description, there is no doubt that he was studying the mosaikkrankheit of Mayer. One of his illustrations shows a spotting which is the same or similar to the spotting described by Mayer and others.

In 1898 Sturgis of Connecticut published a preliminary note on two diseases of tobaceo in which he said:

"If allowed to remain, the paler portions of the mottled leaf loss their green color and the whole leaf becomes yellow and sprinkled over, especially towards the tip, with small cireular spots where the tissues are bleached dead and brittle."

Later on in the same paper he says:

"If that ean be called a disease which is characterized by symptoms such as tobacco-growers desire to see in moderation, which enlance the market value of the leaf and whiclt can be indueed artificially with profit, then the 'spotting' of tobacco comes under this head. It is a peenliar disease, never very common, nor confined to any one locality and not characteristic of any special soil. What its earliest stages are $I$ am unable to say, inasmuch as it is imposible to predict when it will oceur and therefore to be on the watch for its first appearance, and, furthermore, because it only becomes noticeable when well advanced. As I have seen it in the field and in specimens sen't to the Station, it is signalized by the presence on the leaf of small cireular spots. These usually occur in the greatest number at or near the tips of the leaves and, at first, are yellowish in color and somewhat irregular in outline. Later they take on a circular form and become marked off from the surrounding tissue by a narrow border of a darker color. The tissue within this border finally dies and becomes almost white, but, exeept in severe eases, it does not break away from the leaf. A leaf so affected looks as thougl it had been sprinkled over with some caustie substance which has killed the tissues without disintegrating them. It bears a close resemblance also to the 'leaf-spot' eaused on eertain plants by the attacks of fungi. Sometimes the spotting is slight and the spots themselves are seattered evenly over the whole leatsurface; in such cases buyers are willing to pay a higher price for tobaceo, spotted wrappers being in demand. The spot ean be successfully imitated by spraying the ripening leaves with a caustic liquid, and, where this is well done, the tobaceo also brings a ligher price.

"It is only when the spot invades practically the whole leaf and causes the breaking of the tissues that it does serious damage. I lave already repeatedly, but thus far unsucessfully, attempted to discover the primary cause of this 
trouble both by consulting the opinion of experienced tobacco-growers and by careful microscopic examination of the spots. Some say that it is to particles of sand adhering to the leaves; others that it is eaused by drops of water, which, acting as lenses, burn the leaf where they rest; but with regard to these theories it is sufficient to say that they have been put to proof in many attempts to produce the spot artificially and have signally failed. Scores of the spots have been mieroscopically examined during the past three years without showing any evidence of the presence of fungi, insects or bacteria. Nothing further, therefore, can be said regarding this trouble, nor would it have been considered worthy of mention at present were it not for its resemblance to a disease of tabacco which oceurs in Europe and Asia."

In 1902 Woods referred to a spotting of mosaic tobacco leaves which he described as follows:

"In field conditions as a final stage the swollen green area became marked with small dead spots, but these did not appear in plants grown under glass."

In 1914 Clinton reported a spotting of mosaic tobacco leaves which he described as:

"A serious leaf injury known locally as 'rust' often oecurs on the older ealicoed leaves. It slows as small, roundish, reddish-brown spots of dead tissue, more or less thickly covering the leares; sometimes these merge into large irregnlar areas, resembling sun seoreh injury of the plants. This is probably the same trouble described by various European writers as 'pockenkrankheit', aseribed by some to bacteria. In this state rust is not a necessary accompaniment of ealico, but rarely if ever occurs exeept on leaves showing ealico or signs of suppressed calico. We believe that it is of the nature of sun scorch, sinee it usually oecurs in bright, hot weather, suddenly following a rainy or cloudy period, and that it develops on calicoed leaves because of their weakened conditions."

Material from these spots and the surrounding tissues was prepared for embedding and sectioning. The writer was especially interested in this work because of his previous studies which led ti) the conclusion that the chlorotic area's were the result of inhibition and disintegration of the chloroplasts.

$A$ careful study of loth free hand and microtone sections of these spots showed that the spots originated in the palisade cells (Figs. 1 to 8 ). It was impossible to determine whether they originated as small spots which gradually enlarged or whether the spot was full sized from the beginning but the fact that the spots (ievelop during a single night indicates that they are full sized firom a very early stage in their formation. The sections revealed many spots which consisted of a single cell and which could not he detected with the maided eye (Fig. 2). Others ranged from small groups of a few cells (Figs. 1 to 9 ) to areas $5 \mathrm{~mm}$. or occasionally more in diameter. The dying of the palisade cells is followed 
by a dying of the cells below. This usually continues until all the cell's from the upper to the lower surface are dead (Figs. 5 to 10). It appears that the palisade and upper epidermal cells may be the only dead cells of the spots on the morning of the first cay and that the lower cells die later. Occasionally dead mesophyll cells are found in position's unrelated to the spots.

Efforts were made to study the disintegration of the cell contents but very little was learned about it probably due to the fact that it appears to break down during the night. However, the entire cell content appears to disintegrate into a homogenous black mass which dries and shrinks from the cell wall. The next step in this process is the collapse of the upper epidermis (Figs. 6, 7, 8, 9). The next step is the breaking of the cell walls throughout the entire area (Fig's. $\bar{\tau}, 8,9$ ). The final step is the contraction and drying so that the entire area beeomes thin. dry and brittle (Figs. $9 \&$ 10).

A careful study of other tobaceo plants has shown similar spots on leaves of plants with other diseases and on leaves that were past maturity, but these were not so common or so abundant as on the 'mosaic plants. A few spots were also on leaves of pepper plants which had been inoculated with the tobaceo virus.

Note: Since the preparation of this manuseript for publication, Johnson and Hoggan have published a paper (8) in which they say :

"Soon after Mayer's work became known, it was claimed by some that his 'Mosaikkrankheit' of tobacco included two distinct diseases, one the true infectious mosaic and the other a supposedly unrelated disease known elsewhere as 'Pockenkranheit'. Although much attention was given to the subject, this disagreement has presisted almost to the present time, though it is now quite genorally conceded that Mayer was correct in his interpretation that necrosis is one of the symptoms of the ordinary tobaceo mosaic virus on tobaceo as well as on certain other hosts."

\section{L.TTERATURE}

1. Beijerinck, M. W. Over een contagioum vivum Fluidum als Oorzaak de Veeckziekte der Tobaklladen. Verslag Koninkl. Akad. van Wetensch. te Amsterdam, Wis. en Natuurk. Afa. van Zaterdag. 6: 229-235. 1898.

2. - On a Possible Cause of the Leaf Spot on Mosaic of Tobacco. Centbl. Bkt. u. Pav. 2 Abt. 5(1): 27-32. 1899.

3. Clinton, G. P. Chlorosis of Plants with Special Reference to Calico of Tobaceo. Conn. Agri. Exp. Station Report for 1914: pp. $357-424$. (1.915). 
4. Cook, Mel. T. Histology and Cytology of Sugar Cane Mosais Journ. of the Dept. of Agric. of Puerto Rico. 9: 5-27. 1925.

5. The Effect of Mosaie on the Content of the Plant Cell. Jour. of the Dept. of Agric. of I'verto Rico. 10: 229-238. 1926.

6. _The Effect of Some Mosaic Disease on Cell Structure and on the Chloroplasts. Journ. of the Dept. of Agri. of Puerto Rico. 14: 69-101. 1930.

7. Iwanowski, D. and Polowzoff, W. Ryabucha bolesn Tobaka, eja pritschini i srelstwo borbi s nejn (The Leaf Spot of the Tobacco). Mem. Acad. Imp. Sci. St. Petersburg 7, (37). 1890.

8. Johnson, J. and Hoggan, I. A. The Challenge of Plant Virus Differentiation and Classification. Science 73: 29-32. 1931.

9. Marchal, Em. La Mosaique du Tobac (Tobacco Mosaie) Revue Mycologique 19: 13, 14. 1897.

10. Mayer, A. Ueber die Mosaikkrankheit des Tabaks. Landw. Versuchs stat 32: 450-467 (1886) Abstract in Journ. of Mycol. 7 : 382-385. 1894.

11. Prillieux et Delacroix. Maladies Bacillaires de Divers Vegetaux (Bacterial Diseases of Some Plants) Compter Rendus 118: 668-671. 1894.

12. Sturgis, W. C. Preliminary Notes on Two Diseases of Tobacco. Comm. Agri. Expt. Station Report for 1898 pp. 242-260.

13. Woods, A. F. Observations on the Mosaic Diseases of Tobacco. U. S. Dept. of Agric., Bureau of Plant Industry Bull. 18. 1902. 
PLATE XIV.
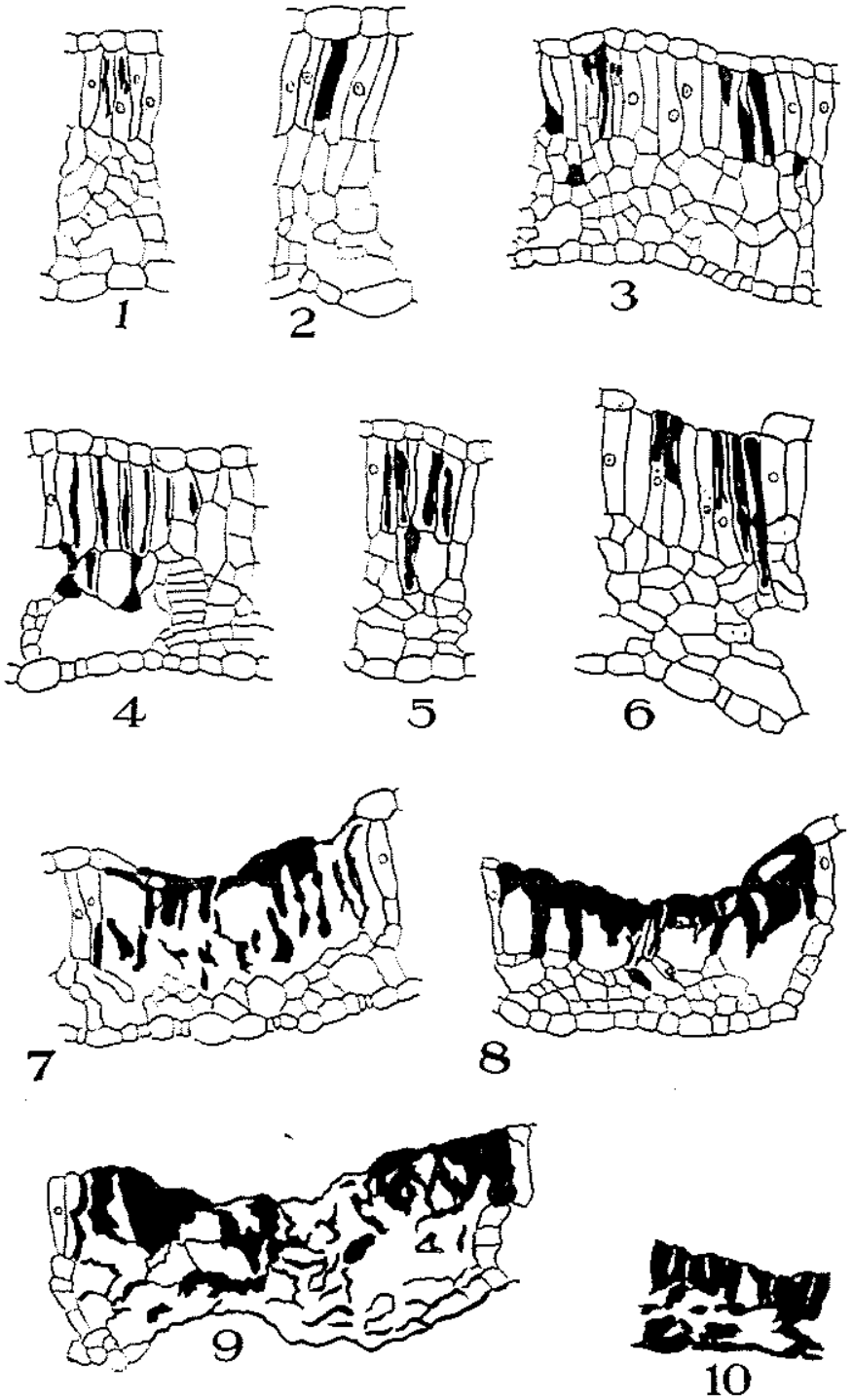